\title{
National systems of production, innovation and competence building
}

By Bengt-Åke Lundvall, Björn Johnson, Esben Sloth Andersen and Bent Dalum, Department of Business Studies, Aalborg University

Version: 27 June 2001.

Abstract: The authors have worked on innovation systems for more than a decade. This paper is an attempt to take stock. In section 2 we reflect upon the emergence and fairly rapid diffusion of the concept 'national system of innovation' as well as related concepts. In section 3 we describe how the Aalborg version of the concept evolved by a combination of ideas that moved from production structure towards including all elements and relationships contributing to innovation and competence building. In section 4 we discuss the challenges involved both in a theoretical deepening of a fairly narrow version of the concept and in the movement toward the broader approach and in adapting the concept for the analysis of poor countries.

Key words: Innovation system, Economic growth, Institutional change, Competence building, Economic development, Innovation policy.

Corresponding author: Bengt-Åke Lundvall, Fibigerstræde 4, DK 9220 Aalborg Ø. Tel: +45 96358248. Fax: +45 9815 6013. E-mail: bal@business.auc.dk. 


\section{Introduction}

The four authors have worked individually and collectively on different aspects of innovation system studies for more than a decade. Actually the common research program leading up to this concept was established more than 20 years ago (Andersen et al., 1978; Andersen et al., 1979). This paper is an attempt to sum up this work and indicate in what direction we believe future work on innovation systems should go. In the first part we give some background on how the concept 'national system of innovation' has developed and spread. In the second part, we tell the story about how the Aalborg-version of the concept developed from being rooted primarily in production structure towards including all elements of the system contributing to competence building. In the third part we discuss the challenges involved both in a theoretical deepening of a fairly narrow version of the concept and in the movement toward the broader approach and how the concept could be adapted in order to be useful for the analysis of countries in the South.

\section{The emergence and spread of the concept of national systems of innovation}

When using an artifact like a computer it is not necessary to know how and by whom it was invented, developed and introduced in the market. Neither is it always necessary in socio-economic research to know how specific analytical tools were shaped. But from time to time it may be useful to reflect on how a concept such as 'national innovation 
systems' came about and to see in what direction it tends to be developed. This is especially the case when the concept cannot be applied smoothly and when attempts are made to develop it further. But even when the purpose is just to apply the concept of national innovation systems in a routine-like manner, some degree of understanding of its background and development may be quite useful. The reason is not least that the concept of national systems of innovation —as its name clearly indicates—combines ideas taken from rather distinct areas of analysis: economic policy, economic interdependence, and more or less radical economic change. The new combination of such elements into the national system of innovation concept is, of course, much more shaky than the integration of the elements of a technological innovation like the modern computer. This fact has to be recognised by users of the concept of national systems of innovation.

\subsection{The unexpected diffusion}

When the idea about the innovation system approach was first discussed in the middle of the 80s nobody expected it to become as widely diffused as it is today. Today OECD, the European Commission and UNCTAD have absorbed the concept as an integral part of their analytical perspective. The World Bank and IMF have been more reluctant but even here change seems to be taking place. The US Academy of Science has recently brought the National Innovation System into its vocabulary and now uses it as a framework for analyzing science and technology policy in the US. Sweden, has given the concept legitimate status in its own particular way by naming a new central government institution (an 'ämbetsverk') VINNOVA which stands for 'the Systems of Innovation Authority'. 
It is interesting to speculate why the concept has diffused so rapidly among scholars and policy makers. One reason may be that mainstream macroeconomic theory and policy have failed to deliver an understanding and control of the factors behind international competitiveness and economic development. Another reason might be that the extreme division of specialization among policy institutions and policy analysts has become such a big practical problem that an analytical concept that helps to overcome these problems was welcomed not least among those responsible for innovation and science policy. It is our impression that the concept to begin with diffused to this more limited community but that it now tends to enter into broader circles of scholars and policy makers focusing on economic growth and development.

The focus on national systems is of course controversial in a context characterized by socalled globalization. Here one might think of 'the owl of Minerva flying in the dusk' and argue that it is only when an institution (in this case the nation state) is becoming seriously threatened that we begin to understand its importance and fundamental functions. But it is also important to note that most empirical studies of how far globalization processes have undermined national systems seem to indicate that the national level remains important for certain innovation activities (Archibugi and Michie, 1995; Cantwell, 1995; Patel, 1995). In a series of studies based on patenting statistics Keith Pavitt and Pari Patel demonstrated that the national origin of multinational firms did matter quite a lot for the location of innovative activities (see for instance Patel and Pavitt, 1994) Actually, it might be argued that the growing proximity and potential tension among national systems brought about by globalisation is a factor increasing the 
demand for understanding nation-specific systemic differences between innovation practices that relate to international trade (Ostry and Nelson, 1995).

\subsection{A concept with roots far back in history}

Although the concept of national systems of innovation is of recent origin, it is helpful to see it as a development of much older intellectual endeavours. The most obvious starting point is Adam Smith's (1776) analysis of the division of labour, which not only included knowledge creation in relation to directly productive activities but also the specialised services of scientists. But Adam Smith did not consider innovation and competence building as independent and systemic. The roots of the discussion of these issues goes rather back to Friedrich List (1841). His concept of national systems of production and learning took into account a wide set of national institutions including those engaged in education and training as well as infrastructures such as networks for the transport of people and commodities (Freeman, 1995). It was focused on the development of productive forces rather than on allocation of given scarce resources. Thus List pointed to the need to build national infrastructure and institutions, which he argued challenged the 'cosmopolitan' approach of Adam Smith. But List obviously lacked the analytical tools for developing his ideas beyond the stage of fairly loose suggestions.

The modern version of the innovation system concept was not based upon any direct inspiration from List. It was only after the concept had become generally accepted that Christopher Freeman and others went back and brought forward List as the intellectual ancestor. The most obvious linkage was perhaps in the development of the Aalborg version of the concept where the role of the home market for innovations has some 
connections to the infant industry argument of List. But, even here, the direct inspiration came via Burenstam Linder who is a liberal economist and a former conservative minister in the Swedish government (Linder, 1961) rather than directly from List.

\subsection{Parallel activities around the world}

Instead of looking for clear-cut intellectual origins of the innovation system concept, its main background should rather be found in the needs of policy makers and students of innovation. The activities of national governments and international organisations like the OECD had during the 1960s and 1970s led to an immense interest in reasons why national growth rates differ and one of the explanations was differences in the research systems of different countries. For researchers who tried to combine general economics with innovation studies such explanations seemed just to scratch the surface of the issue.

It seemed obvious that most of the new knowledge needed for innovation did not come directly from universities and technical research and in many industries not even from research and experimental development but rather from other sources like production engineers, customers, marketing, etc. The problem was to integrate these broader contributions into a concept of the innovation process. The emphasis on this problem meant that the idea of a national system of innovation was immanent in the work of the IKE group in Aalborg already in the first half of the 1980s. A standard phrase found in several publications from this period was 'the innovative capability of the national system of production'. The 'innovation system' concept was 
introduced in Lundvall (1985) but then still without the adjective 'national' added to it.

But the concept was immanent also in the international comparisons between national styles of management of innovation pursued at SPRU and it was Chris Freeman who brought the concept into the literature in 1987 in his book on innovation in Japan (Freeman, 1987). And it was certainly immanent in the work of Dick Nelson and other US-scholars engaged in comparing the US system of science and technology with other national systems. When Freeman, Nelson and Lundvall got together in the big project on technical change and economic theory (Dosi et al., 1988) it ended up with a book where there was a four chapter-section on 'national systems of innovation'. ${ }^{1}$

\subsection{New models}

Over the last decade there have been several new concepts emphasizing the systemic characteristics of innovation but with focus on other levels of the economy than the nation state. The literature on 'regional systems of innovation' has grown rapidly since the middle of the nineties (Cooke, 1996; Maskell and Malmberg, 1997). Bo Carlsson with colleagues from Sweden developed the concept 'technological systems'

Others who worked in parallel along similar lines of thought but with less emphasis on innovation were Michael Porter (1990) and Richard Whitley (1994). Whitley's concept national business system is complementary to the innovation system approach in its emphasis on culturally embedded business practices. (For a comparison see Lundvall, 1999). 
(Carlsson and Jacobsson, 1997) while Franco Malerba developed the concept of ‘sectoral systems of innovation’ (Breschi and Malerba, 1997).

Sometimes these concepts have been presented or interpreted as alternatives to the national system approach and it has been argued that many, if not most, interesting interactions in the context of modern innovation tend to cross national borders and that there is no a priori reason why the national level should be taken as a given for the analysis. Our view on the issue has always been pragmatic and reflects that we see the policy dimension of the concept as important. As long as nation states exist as political entities with their own agendas related to innovation, it is useful to work with national systems as analytical objects.

But the other analytical levels are certainly not only legitimate-they are necessary in order to get a realistic understanding of the working of national systems and, not least, the policy constraints and policy efficiency at the national level. They are also useful in their own right. Regional innovation policy calls for a focus on regional systems and understanding the evolution of global technological systems or sectoral systems is fundamental when it comes to define the needs for supranational co-ordination and rule-setting.

\subsection{On the survival of old paradigms and on competing technologies}

The development of the systemic approach to innovation has taken place in parallel with efforts in economics to integrate knowledge and innovation into neoclassical growth theory as illustrated by the growing interest for 'new growth theory' (Romer, 1990; 
Aghion and Howitt, 1998). These models have big problems with overcoming the linear perspective and in policy analysis we still find a strong presence of the old ideas. The current focus in Europe on bench-marking innovation practices and policies may be seen as a step backwards in this respect (Lundvall and Tomlinson, 2001). The old perspective is far from extinguished.

\subsection{Development studies as a new field of application-or as a re-export}

The modern version of the concept of national systems of innovation was developed mainly in the rich countries — the US, the UK, France and Scandinavia—and to begin with only a narrow circle of academics interested in science and technology policy in these countries used it. Now the interest for the national innovation system perspective is growing strongly in Latin America and Asia. Even in Africa innovation system analysis is beginning to take off.

It is interesting to note that some of the most important elements combined into the innovation system concept actually came from the literature on developing countries-not least from the Schumpeter-inspired development theories of e.g. Hirschman (1958). Such theories contributed with ideas of creative but also systemic feedbacks between different economic activities. More generally, the idea that institutions matter in economic change was more generally accepted for 'less developed countries' than for full blown market economies where it was assumed that the market solves most problems so that institutional 'details' may be pushed into the background. 
To apply the national systems of innovation concept to developing countries may therefore be seen as a kind of 're-export'. Gunnar Myrdal's ideas, inspired from Veblen and fully developed in 'Asian Drama' (1968), of positive and negative feedback, of cumulative causation and of virtuous and vicious circles are inherent in the idea of innovation systems.

\subsection{Adaptation of technology and concepts}

At the end of this paper we will argue that a principal task for future research based on the concept of national systems of innovation is to adapt it in such a way that its application in less developed countries does not result in negative effects on development strategies and that it, on the contrary, helps to stimulate policy learning. We will argue that a major step in this direction is to broaden and deepen the concept and to make it more dynamic. A narrow focus on the role of science and science-based activities is not what is most needed. We need a concept that covers all aspects of competence building in socio-economic activities. We also need to deepen the concept by getting a better understanding of processes of interactive learning. Finally, we need to find ways to capture the formation and evolution of innovation systems from their birth to their death (Andersen and Lundvall, 1997). In order to prepare the ground for such a broadening and deepening of the concept we will take a closer look at how the concept has developed in our own research. 


\section{The evolution of the Aalborg version of the national innovation system concept}

One of Schumpeter's major contributions to the understanding of innovation processes is the interpretation of innovation as a new combination. This concept is important because it brings together two contradictory but important aspects of innovation: its continuity (existing elements) and radical change (the new combination). The Aalborg version of the national system of innovation concept may be seen as a combination of four elements: the neo-Schumpeterian reinterpretation of national production systems, empirical work based on the home market theory of international trade, the microeconomic approach to innovation as an interactive process inspired by research at SPRU and, finally, insights in the role of institutions in shaping innovative activities. ${ }^{2}$ This combination reflects that the concept was developed to get a better understanding of economic growth and trade specialization in a small open economy characterized by high income per capita but with a weak representation of science based firms. It also reflects an emphasis on the economic and technological history of countries with a gradual change in the intra-national and inter-

This specific combination results in an Aalborg version that differs from the US-approach (Mowery and Oxley, 1995) where the analysis is more narrowly focused on institutions as organizations involved in the promotion of science and technology. The combination should be seen in the light of our attempt to develop a framework that is relevant for understanding economic growth and innovation processes in small countries (Freeman and Lundvall, 1988) and it may be seen as a follow-up to a series of contributions to the analysis of the specific problems of small countries (Katzenstein, 1985; Kutznets, 1960; Svennilsson, 1960; Walsh, 1987). 
national division of productive and innovative labour. The focus was to start with macroeconomic issues but it moved gradually also toward issues related to microeconomic dynamics.

\subsection{From systems of production toward systems of innovation}

An important starting point for the IKE group's work in innovation systems was a reinterpretation of what appeared to be the 'structuralist economics' of Dahmén (1970), Hirschman (1958), Perroux (1969), and their followers. Such theorists seemed to have successfully combined Leontief's input-output analysis with Schumpeter's theory of innovation and entrepreneurship. But in practice the input-output perspective easily comes to dominate and 'the missing innovation perspective has led to a misjudgement of some of the important mechanisms to the national and regional development process' (Andersen et al., 1981b, p. 55). It is not easy to recombine Leontief and Schumpeter in a systematic manner (cf. DeBresson, 1996; Drejer, 1999), but the basic idea gave a new and critical interpretation of many analyses of development and growth and the related policies.

One example was that Perroux and his French followers had developed an analysis of the importance of the structure national systems of production for economic dynamics, some of it rooted in the Marxian schemes of extended and intensive reproduction. They assumed that different sectors affect growth differently and that the most dynamic elements in the system (the growth poles) were located upstream. This led them into ordering national systems in a hierarchy. It was assumed that countries such as the US and Germany had a stronger economy than France because 
their production systems were specialized in the production of machine tools. It also led to somewhat naive recommendations for developing countries to establish, at an early stage, activities belonging to the sector producing machinery. The historical experience of the Nordic countries gave an alternative and much more evolutionary perspective, where well-functioning machinery sectors were the outgrowth of strong user sectors and presupposed a long-term innovative interaction with them.

These problems in integrating a Leontief-style analysis of production systems with innovation and entrepreneurship were found in many types of study, so in Aalborg there was much discussion of how to avoid the crowding-out of real neoSchumpeterian perspectives from the theory of growth and development. The immediate solution was to concentrate on a more dynamic approach to vertical linkages in the production system (Dahmén, 1950; Hirschman, 1958; Stewart, 1977). Especially, Dahmén and Hirschman pointed to the opening up of disequilibria as important and sometimes positive drivers in the development process. A related strategy was to apply a life cycle perspective on national systems (Andersen et al., 1978; Andersen et al., 1979). Some of the ideas were later presented for an international audience in Andersen and Lundvall (1988) and Andersen (1992). The analytical building blocks were significantly transformed in the process. First, the importance of backward linkages in the form of flows of information from user sectors was introduced. Second, both learning by doing and learning by searching were introduced in the model. Third, a distinction was made between industrial subsystems at different stages as seen from a life cycle perspective. Fourth, the open economy was explicitly introduced as the analytical framework. With these revisions, the focus 
was now explicitly on the development of new technology in an interaction between user sectors and producer sectors. The quality of demand became an important element in the process. And, while structuralist ideas of the importance of tight national coherence left small countries very limited prospects in terms of growth and wealth, as does the new growth theory today, the Aalborg discussions pointed to a less gloomy future for these countries by emphasizing the qualitative characteristics of the home market.

\subsection{The second element in the combination-the role of the home market for} economic specialization

Some of the early empirical work in Aalborg focused on the division of productive and innovative labour in relation to agriculture, and one interesting result was the strong Danish export specialization in machinery to be used in agriculture and related industries (Andersen et al., 1981a, p. 11). This observation could not be explained without recourse to the role of the home market.

With reference to non-classical and non neo-classical contributions to international trade theory by Posner (1961), Vernon (1966) and especially Linder (1961) a series of empirical studies were pursued showing the importance of the home market when it comes to explain export specialization in process equipment (Dalum et al., 1981; Andersen et al., 1981a). The practical test was to analyze the correlation between specialization indexes for respectively the user and the producer sector commodity. The outcome of the test was that the home-market did play an important role for many process equipment commodities. 
In this context it was established that trade statistics offer good opportunities to characterize and compare the production structure and export specialization of national systems at a rather detailed level. If aggregated in new categories of special relevance for economic growth, specialization data could be used to analyze the competitiveness of national systems. The change over time in the specialization pattern in terms of 'lowtechnology' versus 'high-technology' product was later followed up by similar studies of high-growth and low-growth products. Further, analyzing the relative uniqueness and stability over time of specialization patterns proved to be a way to underpin the idea of

national systems having a certain autonomy (Dalum et al., 1998). Still the studies of more or less aggregate statistics cannot by itself reveal the complex process of innovation. For this purpose is needed not only other types of data (provided by e.g. the DISKO project; see box 1) but also micro-founded theoretical analysis.

\subsection{From innovation as an interactive process to national innovation systems}

The micro assumptions behind the national innovation system approach got theoretical inspiration from Nelson and Winter's evolutionary theory of firms and markets. Another important inspiration came from empirical findings through the 1970s and 1980s made by scholars connected to SPRU and Chris Freeman. The Sappho-study pursued by Freeman and his colleagues at SPRU in the beginning of the seventies (Rothwell, 1977) gave strong support to the idea that success in innovation has to do with long-term relationships and close interaction with agents external to the firm. The presentation of 'the chain-linked model', by Kline and Rosenberg (1986), was important because it gave specific form to an alternative to the cherished linear 
model, where new technology is assumed to develop directly on the basis of scientific efforts, and, thereafter, to be materialized in new marketed products. All this constituted one important step toward the idea of a national innovation system and it indicated a possible micro-foundation of this concept.

The second step was to realize explicitly that the relationships and interactions between agents had to involve non-price relationships. These relationships were presented as organized markets with elements of power, trust and loyalty (Lundvall, 1985). These relationships of co-ordination and co-operation were identified as the only possible solution to the conundrum of product innovations: On the one hand, pure market interactions (prices and quantities only) were found incapable of transmitting the qualitative information between users and producers. On the other hand, the transformation of markets into hierarchies proposed by transaction cost theory did not materialize. In order to understand the dynamics we proposed that the most fruitful perspective was to focus on interactive learning rather than only on transactions.

The third step was to realize that different national contexts offer disparate possibilities for establishing organized markets and processes of interactive learning. A series of studies pointed, for instance, to the long-term character of inter-firm relationships in Japan and contrasted them with the arm's length relationships predominating in the Anglo Saxon countries (Dore, 1986; Sako, 1990). Furthermore, the literature on the importance of trust and the difficulties in transmitting tacit knowledge pointed to a theory of why the national framework matters for the 
boundaries of innovation systems: long-term interactive learning is most easily organised in a setting where there are few linguistic and cultural constraints for the transfer of tacit knowledge and where a multilateral system of trust relationships can most easily be organised.

\subsection{The fourth element in the combination-institutions and institutional economics}

The focus on interactive learning and national boundaries evoke the important role of nationally organised institutions in determining the rate and direction of innovative activities. Early on Johnson (1988) insisted on the importance of institutions for innovation and learning processes. Institutions understood as norms, habits and rules are deeply ingrained in society and they play a major role in determining how people relate to each other and how they learn and use their knowledge (Johnson, 1992). In an economy characterized by on-going innovation and fundamental uncertainty the institutional setting will have a major impact upon how economic agents behave and as well upon the conduct and performance of the system as a whole.

Which are the most important institutions in the context of innovation and the part of the innovation process that is influenced by the national setting? We would like to sort out three institutional dimensions that have a major impact and which may differ across nations: the time horizon of agents, the role of trust and the actual mix of rationality. 
The distinction between short-termism as characterizing corporate governance in Anglo-Saxon countries and long-termism in for instance Japanese investment decisions is one important example of how institutional differences have a decisive influence on the conduct and performance at the national level. It is quite obvious that this distinction is important not only for the allocation of finance but also for other aspects of technical innovation. Certain technologies will only be developed by agents who operate with a long term perspective while others might be easier to exploit with a short term horizon.

Trust is a multidimensional and complex concept which refers to expectations about consistency in behavior, full revelation of what agents regard as relevant information for the other party and restraint in exploiting the temporary weakness of partners. The institutions that constitute trust are crucial for interactive learning and innovation capabilities. The strength and the kind of trust embedding markets will determine to what degree interactive learning can take place in organized markets. Formal and legal arrangements around the market will reflect and have an impact upon this tacit social dimension.

A third category is the pre-dominating rationality. In standard economics it is assumed that instrumental and strategic rationality is always dominating human behavior at least in the private economic sphere. It is correct that economic transactions between anonymous agents and a capitalist environment tend to support instrumental rationality. In a context where learning new skills through interaction with other agents is important for success, it is, however, no longer the only kind of 
behavior that might be selected in the evolving economy. If instrumental rationality were completely dominating the interaction between professors and students, masters and apprenticeships as well as between engineers from R\&D labs belonging to different firms, very little learning would take place. Therefore innovation systems where communicative rationality (Habermas, 1984) played a major role in certain types of activities in the private sector might be better off in the long run than the standard exchange economy. The actual mix of rationality in an innovation system may affect its conduct and performance.

In addition to these informal institutions a number of formal institutional arrangements, like well defined and implemented property rights of different kinds, including intellectual property rights, contract laws, corporate law, arbitration institutions and collective bargaining and other labor market institutions, are of course also important for the working of the economy and more generally recognized as such. In general, we find it useful to think about innovation systems in two dimensions. One refers to the structure of the system-what is produced in the system and what competences are most developed? The second refers to the institutional set up-how does production, innovation and learning take place? Historical analysis may be helpful in demonstrating how the two dimensions co-evolve. Is it the evolution of the structure of production that determines the evolution of the institutional set-up or vice versa and how is match and mismatch between the two reflected in economic growth patterns (Freeman, 1995b)? 


\subsection{The unfinished synthesis}

The above outline of four elements gives a rough impression of how the Aalborg concept of national systems of innovation was developed. The understanding of the innovation process is that it is neither fully automatic as in the theory of induced innovation nor fully deliberate as in theories of R\&D management. The innovation process reflects human initiative and creativity but it is also deeply influenced by the production activities and the institutional setting. The perspective is one where several partners have roles to play in each innovation process. The focus on innovation systems is less reflecting a theoretical abstraction and more the practical needs of the participants in the complex division of productive and innovative labour in modern economies. The highly developed institutional, cognitive and functional specialisation and rapid change give rise to a need to establish innovation-related linkages between the component parts of the system. A crucial part of these linkages still tend to be organised on a national basis because of constraints of language and distance in the necessary co-ordination of decisions and in processes of interactive learning of importance for the innovation process.

Compared to other concepts of innovation systems the Aalborg concept clearly has a complementary role. For instance, the concept implies that national systems of innovation are most important in sectors of production where trust and tacit knowledge play a major role in the innovation process, like in the case of product innovations made for professional users by specialised suppliers. As pointed out by Pavitt (1984) these factors are not equally important in all types of innovation. In 
some sectors a more arms-length approach to innovation seems appropriate, and here the globalized patterns of sectoral innovation systems are more adequate-although the national system of innovation still has a role to play, for instance, through the national supply of scientific personnel. Similarly, the emphasis on the national level of analysis is not intended to remove attention from innovation systems that have their basis within cities and regions or from corporate innovation systems. Still the national level is a quite handy starting point for the inclusion of many aspects of economic specialisation of crucial importance to the innovation process and it is a level where at least some elements policy and development strategies are developed and implemented.

The comparison with other concepts of innovation systems, however, points to a serious limitation of the Aalborg concept of national systems of innovation. The concept is rather broad so although it can be translated into manuals for studies of concrete national systems of innovation, it is not in its present form easily integrated in any theoretical discourse. The pragmatic and flexible character of the concept may be seen as a great advantage since it makes it useful for practical purposes. At the same time we believe that efforts should be made to give the concept a stronger theoretical foundation through additional work in the neo-Schumpeterian and evolutionary economic tradition to make the general concept of national innovation systems better suited as a tool for theoretical economic analysis. In the next section we start with some preliminary ideas to deepen the concept theoretically and after that we pursue a strategy of broadening it to make it more useful for policy coordination and economic development in the south. 


\section{Challenges for the concept of national systems of innovation}

Our on-going research can to some extent be seen as a response to challenges to the concept of national systems of innovation. For brevity we shall only consider four major challenges. The first concerns the need for a clarification and deepening of the concept of national innovation systems. The second is to base the concept much more strongly on the process of learning and competence building. The third has to do with the need to broaden the analysis of economic development and to study how knowledge production is conditioned by and affects social and ecological sustainability. The final challenge is to apply the concept of national innovation systems to innovation policy and to policy coordination.

\subsection{Deepening the concept of national systems of innovation}

The new combination in the Aalborg concept of national innovation systems is obviously developed in the style that Nelson and Winter (1982, pp. 45-48) call 'appreciative theorising', and from a formal viewpoint the synthesis remains unfinished. The incomplete character of the synthesis affects the possibility of studying large-scale phenomena like the creation, transformation and passing away of innovation systems as well as the possibility of a systematic link up to larger bodies of knowledge like e.g. evolutionary theory and more standard theories of growth and development. Although there are no easy responses to this challenge, it might be relevant to summarise some of the efforts in that direction (cf. Andersen, 1996; 1999; Andersen and Lundvall, 1997). 
One way of theoretically constructing the innovation system is to focus on the distinction between public goods and private goods. The general elements of an innovation system may be seen as functional responses to the need to handle this distinction in a way that promotes economic growth. Another way to construct the system and to study its evolution is to regard it as the outcome of a Schumpeterian game where different agents pursue different strategies in terms of innovation, imitation, adaptation, etc. In what follows we will briefly hint at how one might proceed along these two lines of theoretical reasoning.

The functioning of any innovation system reflects the fact that innovative results represent a combination of private and public goods. A formalised technology (like a product design or a process algorithm) can as a piece of fully codified knowledge, be freely applied at any scale of production. The nonrival character of such a technology refers to the fact that it can be adopted by extra firms without influencing the production result of the present adopters. Such a technology may, however, still not be a fully public good if it has some degree of excludability (and appropriability). The firm has several methods (tacitness of technical knowledge, non-disclosure, patenting, etc.) to hold its technology for itself. This excludability explains how the expected revenues from a new technology can more than outweigh its (probabilistic) costs, and thus why private firms undertake innovative activities. However, the fact that exclusion is only partial means that a knowledge spill over arises from the creation of new technology within a firm. The different approaches to excludability are not purely theoretical. On the contrary, economic life and economic policy demonstrate continuous attempts to cope with the problems-not least through trial and error. 
Innovation systems may be seen as historically conditioned, preliminary solutions to these problems. To understand the construction of innovation systems it is, therefore, not sufficient to explore the endogenous institutional evolution of the private sector. The public sector plays a major role when it comes to supplement the self-organising forces of the private sector in at least two respects: enhancement of the production and distribution of technology and the reduction of transaction costs (in the broader context referred to below the reproduction of social and natural capital becomes additional major challenges for government).

In the simplest model we can hardly talk of an innovation system in the strict sense since the activities in other areas and other firms would only have a weak influence on the probability of the innovative success of a particular firm in a particular area: the dominant influence comes from its own innovative activities within that particular area. Even in this simple case the activities of other firms may have some influence on the profitability of a firm's innovative activities. If all firms make innovations with respect to one or a few goods, then the individual firm will have less motivation for doing R\&D than if the firm has a speciality, which is less frequently innovated by other firms. Thus we may even in this simple case distinguish between more and less specialised innovation systems, which differ with respect to innovative duplication and thus aggregate R\&D productivity.

The next step in the analysis is to allow for the introduction of collective solutions where firms collaborate and create technology centres and other forms of inter-firm clearinghouses for the exchange of innovations (cf. Romer, 1993). The innovations are 
individually of minor importance to the innovators, but as a whole they may be of major importance to nationally located industrial sectors. If firms exchange their marginally relevant knowledge via a technology centre, the rate of productivity increase will be larger than if they keep the innovative results for themselves. However, technology centres are confronted with obvious free-rider problems, and historical experience suggests that the viability of self-organised centres should not be overestimated and that normally the public sector has to be heavily involved. Another task for the innovation system is to stabilise the competitive conditions of firms in order to allow them to focus their research efforts. A main function of the different institutions that regulate the appropriability of innovations (patents, etc.) is to allow firms to focus their research and reduce costs of duplication of innovation efforts.

An important step in the analytical process is to introduce the innovative linkages that form a core element of the Aalborg approach. This might be done in terms of an evolutionary game where different firms pursue different Schumpeterian strategies for the exploration and exploitation of new business opportunities (the general setup is inspired by Maynard Smith, 1984 and Sutton, 1998). Firms with such strategies are engaged in a generalised process of Schumpeterian competition. In such a process we see both radical innovators and more adaptation-oriented incremental innovators. Furthermore, it is taken into account that there are both competitive and co-operative ways of relating to the innovations of other firms: some firms imitate while other firms tend to perform complementary innovations. The description of a basic innovation system starts from the classification of the firms that are potentially engaged in new business opportunities according to the different Schumpeterian strategies (or combinations of them). 
In our preliminary studies we have introduced five Schumpeterian strategies: pioneers, adaptionists, imitators, complementors, and mixed strategies. These strategies seem not only to cover Schumpeter's accounts (the first three strategies) but also to reflect the main results of innovation systems studies. Thus the complementor strategy (a concept taken from Nalebuff and Brandenburger, 1996) tries to complement the efforts of the other player by investing in its own, but related, business niche. The effect on the opponent depends on how the niche relates to the core of the business opportunity, but in many cases there will be a symbiosis between complementors and pioneers.

For reasons of bounded rationality and path dependency it is not easy for firms (and other organisations) to change their strategies, so the frequencies of the strategies in a given population will change slowly. The direction of this change is influenced by the original composition of the population. In a population dominated by, for instance, incremental innovators there is an advantage to be a radical innovator and this strategy will tend to increase its frequency. Similarly, radical innovators would perform strongly in a population dominated by complementors while they would perform badly in a population of relatively many imitators. The worst for a would-be radical innovator is, however, to enter a population that is already dominated by radical innovators.

The short discussion of the compatibility problems for the Schumpeterian strategies gives not only a quick insight into the changing composition of the population due to the process of Schumpeterian competition. It also suggests how an innovation system emerges and evolves. As long as the strategy mix of the population of firms (and other organisations) shows large inconsistencies, nobody would see it is an innovation system 
that in a systematic way exploits new business opportunities. But if a (sluggish) process of change has led to a population of firms with a strategy mix that gives a relatively stable coexistence of e.g. radical innovators, incremental innovators and imitators, then it is fairly obvious to think in terms of an innovation system and to try to correct and enhance the system by means of government intervention.

For instance, given a stable strategy mix with a too high proportion of imitators and a too low proportion of radical innovators, the legal framework could be changed to weaken the position of imitators and strengthen the position of radical innovators. Such a policy could, of course, be implemented even in a highly unstable situation, but then the outcome would often be unpredictable. That is one reason why successful innovation policy is most highly developed in relation to fairly stable innovation systems. Through such a policy an augmented innovation system is created. If, however, the basic Schumpeterian game changes (e.g. because of internationalisation, changed intellectual property rights, or public subsidies for R\&D), the mix of strategies in the population will start to move towards another state.

In our preliminary studies we operate with a game where five Schumpeterian strategies co-exist and compete. To use such an analytical scheme to give a stylised presentation of the history of specific national systems of innovation is an interesting challenge. Thus we may try to handle the results from comparative innovation systems studies that seems to describe the Japanese innovation system as based on a relatively stable strategy mix of imitators, adaptionists and complementors (Freeman, 1988) and the stability created by the predominant complementors in the Danish innovation system (Lundvall, 1988; 
Edquist and Lundvall, 1993). These authors also describe the historical emergence of these co-ordinated Schumpeterian strategies. But still the emphasis is on the resultant, full-fledged innovation systems. Only a few researchers put the main emphasis on the transition process between two stable innovation systems (normally in the context of relatively weak economies, cf. Galli and Teubal, 1997). The reason is quite defensible, but there is a lost opportunity to make a further development of the concept of innovation. The idea of systems with co-ordinated frequencies of different Schumpeterian strategies might help to change the situation.

\subsection{Innovation systems in the learning economy}

The theoretical studies sketched out in the previous section tend to move the attention of innovation system studies away from a much needed analysis of the crucial details of learning and competence building. To widen the analysis of national systems of innovation in this direction there is an obvious need to stick to the tradition of appreciative theorising.

In a series of papers we have argued that the last decades have been characterized by a new context that we call 'the learning economy' (Lundvall and Johnsson, 1994; Archibugi and Lundvall, 2001). The new context is more than anything else characterized by a speed up in the rate of change giving a stronger importance to learning processes for economic performance. This is why we argue that today the most important elements in innovation systems have to do with the learning capability of individuals, organizations and regions. The very rapid rate of change gives a premium to those who are rapid learners. This is reflected in the forms of organization inside firms, new mixtures between co-operation 
and competition as well as in new forms of governance. It presents all organizations and especially those specialized in the production, diffusion and use of knowledge for new challenges.

So far, the studies of national systems of innovation have given too little emphasis to the subsystem related to human resource development. ${ }^{3}$ This includes the formal education and training, the labor market dynamics and the organization of knowledge creation and learning within firms and in networks. This subsystem will be confronted with very strong needs for social invention in the near future in all national systems and quite a lot of the peculiarities of national systems are rooted in this sub-system.

Another new focus must be on the part of business services that specialize in producing, gathering and selling knowledge. This sector is growing more rapidly than any other sector and new empirical studies indicate that it is becoming a key sector in the French structural school sense (Tomlinson, 2001). More and more producers of tangible products and traditional services move into this field. To understand how such businesses operate within and across national borders is another key to understanding the future economic dynamics.

The production and diffusion of knowledge is itself changing character. Some elements of knowledge become codified and much more mobile globally while other key integrated in the analysis of what they call 'social systems of innovation'. 
elements remain tacit and deeply embedded in individuals and organizations and localities. To understand better these processes may, actually, be a key to establish a new kind of economy (OECD, 2000). This points to an ambitious theoretical research agenda aiming at understanding processes of learning in the context of production and innovation systems. It has been argued by Marx that what really made the industrial revolution a revolution was not the use of machinery but rather the stage where machinery was used to produce machinery. It may be the case that it is only when we systematically can apply knowledge to the production of knowledge that we will witness the radical consequences of the establishment of the learning economy.

To understand the process of transformation, it is useful to analyze and understand how specific national systems respond to global trends and challenges. Some national systems may, for historical reasons, be better prepared to cope with the new context than others. Some systems may be more innovative than others when it comes to develop policy strategies and institutional reforms that respond to the new challenges. The Danish system of innovation and competence building is small in global terms but it has certain characteristics that might make it interesting as one possible 'model' for international institutional learning (see box 1). ${ }^{4}$ Denmark is one of the most egalitarian societies in the world in terms of income distribution and at the same time it has an

4 It is interesting to note that the on-going OECD project on economic growth in the context of 'the new economy' Denmark, Norway, Finland and other small egalitarian societies appear together with the US as the success stories. Also it is concluded that there is no simple relationship between inequality and economic growth. 
income level that is among the highest in the world. It has a high degree of gender equality and well-developed local democracy. These characteristics influence the Danish innovation system.

\section{(Box 1 approximately here)}

In the present era of the globalizing learning economy (Lundvall and Borras, 1998; Lundvall, forthcoming) there are contradictions inherent in the economic process that threaten learning and competence building by undermining social capital. Financial speculation seems to become more and more unhampered and increasingly it is finance capital that judges what is 'good-practice' among firms as well as among governments. This power of financial capital is one of the major factors that speed up the rate of change and thereby the need for accelerating learning. At the same time the uninhibited rule of finance capital gets into serious conflict with some of the fundamental prerequisites for the sustainability of the learning economy. It is a fundamental contradiction that financial capital that is 'silly capital' dominates an economy based upon learning and knowledge.

On the one hand short-term economic calculations and speedy processes of decisionmaking (especially in financial flows) are getting more and more important (Jessop, 1999). On the other hand competition depends more and more on dynamic efficiency rooted in knowledge or knowledge related resources with long-term characteristics. These resources often take a long time and sustained efforts to build but they may also be quickly destroyed. This is because learning and innovation are interactive processes, which depend on trust and other elements of social cohesion. 
One problem is that the speed-up of change puts a pressure on all kinds of established social relationships in local, regional and national communities. It contributes to the weakening of traditional family relationships, local communities and stable workplaces. This is important since the production of intellectual capital (learning) is strongly dependent on social capital. To find ways of re-establishing the social capital undermined by the globalization process is a major challenge.

Another problem is that the short term perspectives promoted by financial capital give little weight to long term ecological imbalances. The discount rates are very high not only when it comes to assess future benefits but also when it comes to assess ecological costs. Natural capital including unpolluted air in the big cities and clean drinking water is not sufficiently valued in a regime dominated by a governance form where finance capital is directly or indirectly in charge.

These contradictions in the learning economy increase the need for policy co-ordination. Below we will argue that there is a need for policy learning in terms of building new kinds of institutions for policy co-ordination. Such institutions would have as strategic responsibilities to develop a common vision for how to cope with the challenges and contradictions of the globalizing learning economy. At the national level such a vision has to be based on a deep understanding of the distinct national system of competence building and innovation on the one hand and of the major trends in the global context on the other. 


\subsection{Innovation systems and economic development}

As mentioned above the concept of innovation systems has mostly been applied to problems of growth and development in the high-income countries of the North. However, it is our contention that it is highly relevant also for the South. There are different conceptualizations of innovation systems but when explicitly focusing on the South the broad approach applied in the DISKO project is to be preferred (Lundvall, forthcoming). Here, innovations are seen as rooted in everyday activities in firms and in the competencies and capabilities of ordinary of people.

Innovation systems work through the introduction of knowledge into the economy (and into the society at large). It requires active learning by individuals and organizations taking part in processes of innovation of different kinds. The efficiency of these learning activities and, hence, the performance of the innovation systems depends of economic, political and social infrastructures and institutions. It also depends on past experiences as they are reflected in the tangible and intangible aspects of the structure of production and on values and policies. The learning capabilities, which are instrumental in the innovation process, are also values in their own respect. This is also the case for possibilities for education and participation in democratic processes. In fact many of the factors that make people effective learners may be viewed also as constitutive parts of development.

It follows that there are good reasons for using a broad concept of innovation system in connection to development analysis both when focusing on countries in the North and in the South. However, the reasons seem to be strongest for the South. A narrow innovation system concept focusing on the research and development system and on high tech and 
science-based innovations make even less sense in the South. There are several reasons for this.

In a relatively 'complete' national system of innovation it may be less problematic to analyze a specific subsystem. If there are adequate knowledge infrastructures and intellectual property rights and if there are good networking capabilities and high levels of trust, there is also a suitable basis for an efficient research and development system. It may then be quite possible to analyze the details of this subsystem without worrying too much about the rest of the innovation system. But this is typically not the case in the South, which makes a broad approach preferable. It is a fact that successful developing countries are good in linking up to the national systems of innovation in more developed countries (Hobday, 1997), but even in this case a broad approach is called for because of the many factors that are influencing this relationship.

Another reason is that the need to take into account local and traditional knowledge may be relatively bigger in the South than in the North. The broader approach pays attention to tacit knowledge (Polanyi, 1958; Polanyi, 1966) and to the need not to loose important parts of largely not codified and undocumented local competencies. Local knowledge is easily de-learnt and forgotten when economies are opened up to international competition and societies accordingly restructured. A broad concept of innovation systems helps to see the importance of different kinds of knowledge and the ways they complement each other (Ernst and Lundvall, 1997).

The often very uneven distribution of both constitutive and instrumental freedoms in the South makes it important not to focus only on the relatively strong and internationally 
competitive parts of the economy. Also for this reason a broad innovation systems approach should be endorsed.

When applied to countries in the South it is important to be aware of some weaknesses of the innovation system approach, as it has been used so far. Some of these have directly to do with the fact that it has mostly been applied to the North. It has been used mainly as an ex-post rather than as an ex-ante concept (Arocena and Sutz, 2000). It has been used to describe, analyze and compare relatively strong and diversified systems with well developed institutional and infrastructure support of innovation activities. It has not, to the same extent, been applied to system building. When applied to the South the focus ought to be shifted in the direction of system construction and system promotion. Furthermore, the relationships between globalization and national/local systems need to be further researched. It important to know more about how globalization processes affect the possibilities to build systems of innovation in developing countries and local systems are important parts of this.

Another weakness of the system of innovation approach, is that it is still lacking in its treatment of the power aspects of development. The focus on interactive learning-a process in which agents communicate and even cooperate in the creation and utilization of new economically useful knowledge — may lead to an underestimation of the conflicts over income and power, which are also connected to the innovation process. Interactive learning and innovation immediately sounds like a purely positive sum game, in which everybody gain. In fact, there is little learning without forgetting. Skills and competencies are rejected and destroyed and many people experience decreasing income and influence. 
Increasing rates of learning and innovation may lead not only to increasing productivity and income but also to increasing polarization in terms of incomes and employment. It may be more common in the south than in the north that interactive learning possibilities are blocked and existing competences destroyed (or de-learnt) for political reasons related to the distribution of power.

It is true that it does not have to be like that. Different types of (integrated) policies might counteract the tendency. But the tendency is, certainly, inherent in the learning economy and counteracting policies are in more short supply in the South than in the North. Furthermore, a certain amount of stability in the macroeconomic and financial environment, including well behaved, not too conflict provoking, fiscal and monetary policies, is important for interactive learning and innovation. Again, such stability is typically lacking in developing countries.

It is thus, clear that the innovation system approach needs to be adapted to the situation in developing countries if it is to be allied to system building. It seems also clear, however, that the holistic and systemic character of the approach and its focus on production based tacit knowledge and on learning by doing, using and interacting should make it possible to implement such adaptations.

\subsection{Innovation policy}

When it comes to supporting innovation processes through different kinds of policy there is a growing consensus on the need to focus on long term competence building in firms and in society as a whole. At the same time, the prevailing institutional set up and global 
competition tends to give predominance to short term financial objectives in policy making. At the institutional level this is reflected in the fact that ministries of finance have become the only agency taking on a responsibility for co-ordinating the many specialized area policies. Area specific ministries tend to identify with their own 'customers' and take little interest in the wider objectives of society.

A broad concept of innovation system implies a new perspective on a wide set of policies including social policy, labour market policy, education policy, industrial policy, energy policy, environmental policy and science and technology policy. Specifically, the concept calls for new national development strategies with co-ordination across these policy areas.

All these area specific policies affect learning and competence building. They need to be designed with this in mind and brought together and attuned into a common strategy. It is highly problematic to leave policy co-ordination exclusively to ministries of finance and to central banks since their visions of the world are necessarily biased toward the monetary dimension of the economy and thereby toward the short term. The analytical efforts aiming at increasing our understanding of the regional, national and transnational innovation systems need to be supported by new policy institutions in the form of high level councils for innovation and competence building at these levels. Such councils should be given authority to take into account issues of social and ecological sustainability and the power to counter short-term views of finance capital.

Another important potential of applying the innovation system concept and to pursue comparative studies of different systems is that it helps to get a critical understanding of the limits of specific national policy strategies. Policies aiming at promoting industrial 
development through innovation will often tend to follow specific trajectories and often they will be more successful in reinforcing the system where it is already strong. This was our conclusion in Edquist and Lundvall (1993) where we found that Swedish policies were focused on promoting process innovation while Danish policies where more focused on incremental product innovation. In both countries the focus was on reinforcing the strong sides of the system. In order to overcome this kind of lock ins and the impact of vested interests in defining the policy agenda the system perspective and its use in comparative analysis is especially helpful.

In a broader perspective national systems of innovation may be regarded as a tool for analyzing economic development and economic growth. It has in common with growth accounting that it tries to bring together the major factors that affect technical progress as registered in standard neoclassical growth models. Such a perspective may be to narrow, however. As pointed out by Freeman (1997) the ecological challenge ought to be integrated in any strategy for economic development and here we will argue that in the learning economy intellectual and social capital are important elements in the development process. The extended perspective can be introduced as in table 1 below $^{5}$ :

(Table 1 approximately here) to be discussed below. The major difference is that labour is not explicitly introduced in our table. This reflects that we do not regard labour as a resource of the same character as the four kinds of 'capital'. The human factor is the one that puts in motion, integrates and co-ordinates the different kinds of capital. 
The table illustrates that economic growth is faced with a double challenge in terms of sustainability and that there is an immanent risk of undermining not only the material basis of material production. The creation of tangible capital may be threatened by a neglect of environmental sustainability. We will argue that the production and efficient use of intellectual capital is fundamentally depending upon social capital (Coleman, 1990; Fukyuama, 1995; Woolcock, 1998; OECD, 2001). A development strategy that focuses only on production capital and intellectual capital is not sustainable.

Innovation may have a positive role in bolstering sustainability (Johnson, 1998). Technical innovation, for instance in terms of developing substitutes to naturally scarce raw products, may help to overcome the fact that natural capital cannot always be reproduced. In a similar vein social innovation and institutional redesign may help to overcome a crisis where the social capital is foundering. In both cases it is important to note that the workings of unhampered market forces will erode the basis of economic growth. Environmental sustainability was explicitly introduced into a national innovation system approach by Segura-Bonilla (1999).

This perspective indicates a broader and more interdisciplinary approach to economic growth than standard economics. It also differs in being more explicit in terms of the institutional assumptions made and especially in avoiding any assumption about factors being independent. This reflects the system's perspective and the emphasis on virtuous and vicious circles or match and mismatch between elements and subsystems. Some of the 
most fundamental contradictions in the new context can also be referred to in terms of problems to reproduce natural and social capital. ${ }^{6}$

\section{Concluding remarks}

The concept of national systems of innovation has evolved and diffused quickly during the last few years. This development has emphasised the need of sharpening the concept and the related policies, and we are confident that much progress will be seen in this vein. There is, however, a tendency to concentrate the efforts in the rich North. Therefore, we shall use our concluding remarks on the possibilities of widening the concept and its applications.

We believe that the broad concept of national system of innovation may be useful as an analytical tool and as a tool for promoting sustainable economic growth and well-being also in countries in the South. At the same time, we recognize the need to adapt and further develop the concept so that it becomes more adequate for the situation in these countries.

On the positive side it points to a legitimate national mobilization of efforts and to a coordinated policy effort to enhance learning capabilities necessary in order to get started a

6 The manifold use of the concept of capital may be criticized. An alternative view could be that the confusion in economics about different meanings of capital is already such that it is as well to loosen up the concept even more in order to split the illusion that capital has a clear meaning in economics. 
new type of dynamics in these countries. In order to do so it needs to inspire activities that mobilize broadly across sectors and regions.

On the negative side there is always a risk that the concept becomes misinterpreted as a basis for promoting exclusive science-based institutions and activities with very limited socio-economic impact. There is a need for broad efforts to promote the learning capability including that of weak segments of the population and of the country.

Also analytical efforts to better understand how more complete innovation and competence building systems may be constructed in the present environment of global competition and networking need to be made. The power games of exclusion and inclusion in relation to global knowledge-intensive networks has become of key importance for development.

\section{References}

Adelman, I., 1963. Theories of Economic Growth and Development, Stanford, Stanford University Press.

Amable, B., Barré, R. and Boyer, R., 1997. Les systémes d'innovation a l'ére de la globalization, Paris, Economica.

Aghion, P. and Howitt P., 1998. Endogenous Growth Theory, Cambridge Mass. MIT Press. 
Andersen, E.S., 1992. 'Approaching National Innovation Systems', in Lundvall, B.-Å. (Ed.), National Innovation Systems, London, Pinter Publishers.

Andersen, E.S. (1996), 'From Static Structures to Dynamics: Specialisation and Innovative Linkages', in DeBresson, C. (Ed.) Economic Interdependence and Innovative Activity: An Input-Output Analysis, Aldershot, Elgar.

Andersen, E.S., 1999. 'Multisectoral Growth and National Innovation Systems', Nordic Journal of Political Economy, 25 (1).

Andersen, E.S., Johnson. B. and Lundvall, B.-Å., 1978. Industriel udvikling og industrikrise, Serie om industriel udvikling no. 4, Aalborg, Aalborg University Press.

Andersen, E.S., Brændgaard, A., Johnson. B. and Lundvall, B.-Å., 1979. Industriel udvikling og international konkurrenceevne, Serie om industriel udvikling no. 6, Aalborg, Aalborg University Press.

Andersen E. S., Dalum, B. and Villumsen, G., 1981a. International Specialisation and the Home Market: An Empirical Analysis, Aalborg, Aalborg University Press.

Andersen, E.S., Dalum, B., and Villumsen, G., 1981b. 'The Importance of the Home Market for Technological Development and the Export Specialization of Manufacturing Industry', in Freeman, C. et al. (Eds), Technical Innovation and National Economic Performance, Aalborg, Aalborg University Press, pp. 49-102. 
Andersen, E.S. and Lundvall, B.-Å., 1988. 'Small National Innovation Systems Facing Technological Revolutions: An Analytical Framework', in Freeman, C. and Lundvall, B.-A. (Eds), Small Countries Facing the Technological Revolution, London, Pinter Publishers.

Andersen, E.S. and Lundvall, B.-Å., 1997. 'National innovation systems and the dynamics of the division of labor', in Edquist, C. (Ed.), Systems of Innovation: Technologies, Institutions and Organizations, London, Pinter Publishers.

Archibugi, D. and Pianta, M., 1992. The technological specialization of advanced countries, Dordrecht, Kluwer Academic Publishers.

Archibugi, D. and Michie, J., 1995. 'The globalization of technology: a new taxonomy', in Cambridge Journal of Economics, 19 (1).

Archibugi, D. and Lundvall, B.-A. (Eds), 2001. Europe in the Globalising Learning Economy, Oxford University Press.

Bertalanffy, L., 1968. General System Theory, New York, George Braziller.

Breschi, S. and Malerba, F., 1997. 'Sectoral innovation systems', Edquist, C. (Ed.), Systems of Innovation: Technologies, Institutions and Organizations, London, Pinter Publishers.

Cantwell, J.A., 1995. 'The globalization of technology: What remains of the product cycle model?', in Cambridge Journal of Economics, 19 (1). 
Carlsson, B. and Jacobsson, S., 1997. 'Diversity creation and technological systems: A technology policy perspective', in Edquist, C. (Ed.), Systems of Innovation: Technologies, Institutions and Organizations, London, Pinter Publishers.

Castells, M., 1997. The Rise of the Network Society, Maldon Mass. and Oxford, Blackwell.

Coleman J., 1990. Foundations of Social Theory, London, Harvard University Press.

Cooke, P., 1996. 'Regional innovation systems: An evolutionary approach', in Baraczyk, H., P. Cooke and R. Heidenriech (Eds), Regional Innovation Systems, London, London University Press.

Dahmén, E., 1970. Entrepreneurial Activity and the Development of Swedish Industry 1919-1939, Homewood, American Economic Association Translation Series.

Dalum, B. et al., 1981. Økonomiers langsigtede udvikling: en struktur og teknologidiskussion, Aalborg University.

Dalum, B., Laursen, K. and Villumsen, G., 1998. 'Structural Change in OECD Specialisation Patterns: Specialisation and "Stickiness", International Review of Applied Economics, 12 (3).

DeBresson, C. (Ed.), 1996. Economic Interdependence and Innovative Activity: An InputOutput Analysis, Aldershot, Elgar. 
Drejer, I., 1999. Technological Change and Interindustrial Linkages: Introducing Knowledge Flows in Input-Output Studies, PhD Thesis, Aalborg University.

Dore, R., 1986. Flexible rigidities: Industrial policy and structural adjustment in the Japanese economy 1970-1980, London, Athlone Press.

Dosi, G., Freeman, C., Nelson, R.R., Silverberg, G. and Soete, L. (Eds), 1988. Technological Change and Economic Theory, London, Pinter Publishers.

Edquist, C. (Ed.), 1997. Systems of Innovation: Technologies, Institutions and Organizations, London, Pinter Publishers.

Edquist, C. and Lundvall, B.- $\AA$., 1993. 'Comparing the Danish and Swedish Systems of Innovation', in Nelson, R.R. (Ed.), National Innovation Systems: A Comparative Analysis, Oxford, Oxford University Press.

Ernst, D. and Lundvall, B.- $\AA$., 1997. 'Information technology in the learning economy: Challenges for developing countries', DRUID Working Paper 97-11, Aalborg, Department of Business Studies.

Fransman, M., 1995. Japan's Computer and Communications Industry, New York, Oxford University Press.

Freeman, C., 1987. Technology Policy and Economic Performance: Lessons from Japan, London, Pinter Publishers. 
Freeman, C., 1988. 'Japan: A new National Innovation Systems?', in Dosi, G., Freeman, C., Nelson, R.R., Silverberg, G. and Soete, L. (Eds), Technical Change and Economic Theory, London, Pinter Publishers.

Freeman, C., 1995a. 'The National Innovation Systems in historical perspective', in Cambridge Journal of Economics, 19 (1).

Freeman, C., 1995b. 'History, co-evolution and economic growth', in IIASA Working Paper 95-76, Laxenburg, IIASA.

Freeman, C., 1997. Innovation systems: City-state, national, continental and subnational, Mimeo, Paper presented at the Montevideo conference, University of Sussex, SPRU.

Freeman, C. and Lundvall, B.-A. (Eds), 1988. Small Countries Facing the Technological Revolution, London, Pinter Publishers.

Fukyama, F., 1995. Trust: The Social Virtues and the Creation of Prosperity, London, Hamish Hamilton.

Galli, R., and Teubal, M., 1997. 'Paradigmatic Shifts in National Innovation Systems', in Edquist, C. (Ed.), Systems of Innovation: Technologies, Institutions and Organizations, London, Pinter Publishers.

Gibbons, M., Limoges, C., Nowotny, H., Schwartzman, S., Scott, P. and Troiw, M., 1994. The New Production of Knowledge, Sage, London. 
Guerreri, P. and Tylecote, A., 1997. 'Interindustry differences in technical change and national patterns of technological accumulation', in Edquist, C. (Ed.), Systems of Innovation: Technologies, Institutions and Organizations, London, Pinter Publishers.

Habermas, J., 1984. The Theory of Communicative Action, Vol. I, Boston, Beacon Press.

Hirschman, A.O., 1958. The Strategy of Economic Development, Clinton Mass.: Yale University Press.

Hobday, M., 1997. Innovation in East Asia, London, Edward Elgar.

Jessop, B., 1999. 'The state and the Contadictions of the Knowledge-Driven Economy', Development Research Working Papers, Department for Development and Planning.

Johnson, B., 1988. 'An Institutional Approach to the Small Country Problem', in Freeman and Lundvall (Eds), Small Countries Facing the Technological Revolution, London and New York, Pinter Publishers.

Johnson, B., 1992. 'Institutional learning', in Lundvall, B.-Å. (Ed.), National Innovation Systems: Towards a Theory of Innovation and Interactive Learning, London, Pinter Publishers.

Johnson, B., 1998. 'Institutional Learning and Clean Growth', in Tylecote A. and van der Straaten, J. (Eds) Environment, Technology and Economic Growth, Elgar Publishing. 
Katzenstein, P. J., 1985. Small States in World Markets. Industrial Policy in Europe, New York, Cornell University Press.

Kline, S. J. and Rosenberg, N., 1986. 'An overview of innovation', in Landau, R. and Rosenberg, N. (Eds), The Positive Sum Game, Washington D.C., National Academy Press.

Kutznets, S., 1960. 'Economic Growth of Small Nations', in Robinson, E.A.G. (Ed.), Economic Consequences of the Size of Nations, Proceedings of a Conference held by the International Economic Association, Macmillan, London.

Linder, S.B., 1961. An Essay on Trade and Transformation, New York, Wiley.

List, F., 1841. Das Nationale System der Politischen Ökonomie, Basel: Kyklos (translated and published under the title: The National System of Political Economy' by Longmans, Green and Co., London 1841).

Lundvall, B.-Å., 1985. Product Innovation and User-Producer Interaction, Aalborg, Aalborg University Press.

Lundvall, B.-Å., 1988. 'Innovation as an interactive process: From user-producer interaction to the National Innovation Systems', in Dosi, G., Freeman, C., Nelson, R.R., Silverberg, G. and Soete, L. (Eds), Technical Change and Economic Theory, London, Pinter Publishers. 
Lundvall, B.-Å. (Ed.), 1992. National Innovation Systems: Towards a Theory of Innovation and Interactive Learning, London, Pinter Publishers.

Lundvall, B.- $\AA$., 1999. 'National Business Systems and National Innovation Systems' International Studies of Management and Organization.

Lundvall, B.-^̊., forthcoming. Innovation, Growth and Social Cohesion: The Danish Model, London, Edward Elgar.

Lundvall, B.-Å. and Borras, S., 1998. The Globalising Learning Economy: Implications for Innovation Policy, Bruxelles, DG XII-TSER, the European Commission.

Lundvall, B.-Å. and Johnson, B., 1994. 'The learning economy', Journal of Industry Studies, 1 (2), 23-42.

Lundvall, B.-Å. and Tomlinson, M., 2001. 'Learning by comparing: Reflection on the use and abuse of benchmarking', in Sweeney, G. (Ed.), Innovation, Economic Progress and Quality of Life, London, Elgar Publishers.

Maskell, P., Eskelinen, H., Hannibalsson, I., Malmberg, A. and Vatne, E., 1998. Competitiveness, Localised Learning and Regional Development. Specialisation and Prosperity in Small Open Economies, London: Routledge.

Maynard Smith, J., 1982. Evolution and the Theory of Games, Cambridge, Cambridge University Press. 
McKelvey, M., 1991. 'How do National Innovation Systems differ?: A critical analysis of Porter, Freeman, Lundvall and Nelson', in Hodgson, G. M. and Screpanti, E. (Eds), Rethinking Economics: Markets, Technology and Economic Evolution, Aldershot, Elgar Publishing.

McKelvey, M., 1997. Using evolutionary theory to define National Innovation Systems, in Edquist, C. (Ed.), Systems of Innovation: Technologies, Institutions and Organizations, London, Pinter Publishers.

Mowery, D.C. and Oxley, J.E., 1995. 'Inward technology transfer and competitiveness: the role of National Innovation Systems', in Cambridge Journal of Economics, 19 (1).

Myrdal, G., 1968. Asian Drama: An Inquiry into the Poverty of Nations, Vol I-III, Penguin Books

Nalebuff, B.J., and Brandenburger, A.M., 1996. Co-opetition, London, HarperCollins.

Nelson, R. R., 1988. 'Institutions supporting technical change in the United States', in Dosi, G., Freeman, C., Nelson, R.R., Silverberg, G. and Soete, L.,(Eds), Technical Change and Economic Theory, London, Pinter Publishers.

Nelson, R.R. (Ed.), 1993. National Innovation Systems: A Comparative Analysis, Oxford, Oxford University Press.

Nelson, R.R., and Winter, S.G., 1982. An Evolutionary Theory of Economic Change, Cambridge, Mass. and London, Belknap Press. 
OECD, 2000. Knowledge Management in the Learning Economy, Paris, OECD.

OECD, 2001. The Well-being of Nations, The Role of Human and Social Capital, Paris, OECD.

Ostry, S. and Nelson, R. R., 1995. Techno-nationalism and techno-globalism: Conflict and co-operation, Washington D.C., Brookings Institution.

Patel, P., 1995. 'Localized production of technology for global markets', in Cambridge Journal of Economics, 19 (1).

Patel P. and Pavitt K., 1994. 'Technological Competencies in the world's largest firms: complex and path-dependent, but not too much variety', Research Policy, 23, 533-546.

Pavitt, K., 1984. 'Sectoral Patterns of Technical Change: Towards a Taxonomy and a Theory', Research Policy, 13, 343-373.

Perroux, F., 1969, L'Économie du XXe siècle, 3rd edn., Presses Universitaires de France, Paris.

Polanyi, M., 1958/1978. Personal Knowledge, London, Routledge \& Kegan.

Polanyi, M., 1966. The Tacit Dimension, London, Routledge \& Kegan.

Porter, M., 1990. The Competitive Advantage of Nations, London, MacMillan.

Romer, P.M., 1990. 'Endogenous technological change', Journal of Political Economy, 98. 
Romer, P.M., 1993. 'Implementing a National Technology Strategy with Self-Organizing Industry Investment Boards', Brookings Papers on Economic Activity: Microeconomics.

Rosenberg, N., 1982. Inside the Black Box: Technology and Economics, Cambridge, Cambridge University Press.

Rothwell, R., 1977. 'The characteristics of successful innovators and technically progressive firms', R\&D Management, 7 (3), 191-206.

Sako, M., 1990. 'Buyer-supplier relationships and economic performance: evidence from Britain and Japan', Ph. D. thesis, University of London.

Segura-Bonilla, O., 1999. Sustainable Systems of Innovation: The Forest Sector in Central America, SUDESCA Research Papers No 24, PhD dissertation, Department of Business Studies, Aalborg University.

Svennilson, I., 1960. 'The Concept of the Nation and its Relevance to Economic', in Robinson, E. A. G. (Ed.), Economic Consequences of the Size of Nations, Proceedings of a Conference held by the International Economic Association, Macmillan, London.

Stewart, F., 1977. Technology and Underdevelopment, London.

Sutton, J., 1998. Technology and Market Structure: Theory and History, Cambridge, Mass. and London, MIT Press. 
Tomlinson, M., 2001. 'A new role for business services in economic growth', in Archibugi, D. and Lundvall, B.-Å. (Eds), Europe in the Globalising Learning Economy, Oxford, Oxford University Press.

Tylecote, A., 1994. 'Financial systems and innovation', in Dogson, R. and D. Soskice (Eds), Handbook of Industrial Innovation, Cheltenham, Edward Elgar.

Walsh, V., 1987. 'Technology, competitiveness and the special problems of small countries', OECD, STI Review, 2, 81-133.

Whitley, R., 1994. 'Societies firms and markets: The social structuring of business systems', in Whitley, R. (Ed.), European Business Systems, London, Sage Publications.

Woolcock, M., 1998. 'Social capital and economic development: Toward a theoretical synthesis and policy framework', Theory and Society, 27 (2), 151-207. 


\section{Box 1: Six lessons from the DISKO study}

The DISKO study was a large-scale project on the Danish System of Innovation in a Comparative Perspective, mainly carried out 1996-1999. Apart from a large number of reports in Danish language, there is also an increasing number of English papers based in the project's unique databases. A general account for the results is found in Lundvall (forthcoming). Here are some highlights:

Lesson no 1, On the compatibility of equality and growth: The Danish economy is one of the most egalitarian in the world in terms of income distribution and it is among the ones with the highest GNP/capita. The growth success of the US has gone hand in hand with increasing inequality. The experience of Denmark demonstrates that there is no necessary connection between strong growth and growing inequality.

Lesson no 2, On the compatibility of flexibility and security in the labour market: In international organisations such as OECD there has been a general message to increase flexibility in labour markets. Trade unions have opposed and pointed to the need for security. The Danish data show that the forms of flexibility that are most adequate in the learning economy are compatible with security among wage earners. High mobility between employers has not resulted in insecurity among employees because the social security provision has been acceptable. In Denmark, the introduction of functional flexibility within firms tends to reduce the need for numerical flexibility.

Lesson no 3, On the importance of innovation in low technology sectors: One of the interesting aspects of the Danish system is that its relative wealth has been built in spite of a specialization in low technology sectors and that most of its innovations are incremental and experience-based rather than radical and science based. Supporting innovation in low technology areas will remain an important priority for industrial policy. In the light of the 'new economy'-discourse there might be a risk to forget about the renewal of competence in traditional sectors, including service sectors.

Lesson no 4, People and career patterns matter for the formation of networks: The Danish economy is characterised by intense interaction between firms while the interaction between firms and universities is weakly developed. As demonstrated in this study this characteristic reflects the composition of the labour force in firms and the absence of academic personnel in many small and medium-sized firms. A general conclusion is that network formation and establishing new linkages may best be established by affecting career patterns and incentive systems in firms and at universities.

Lesson no 5, What matters most is learning to learn and learning organizations: The rapid rate of change undermines established competence and requires the continuing establishment of new ones. Firms that become learning organisations are more productive and more innovative. They create more and more stable jobs. Much of the resistance is found at the top rather than at the bottom of the organisation. Promoting organisational change is becoming a crucial element of innovation policy. Education and training institutions need to focus on learning students to learn.

Lesson no 6, Social capital matters for growth and the need for a new new deal: The only way to explain the strong economic performance of Denmark and other small economies with a weak specialisation in high technology products is to take into account the social capital that makes it easier for people to learn, collaborate and trade. The most important threat to this mode of production and innovation is the growing polarisation and exclusion of those who do not fit into the learning economy. To give those a stronger learning capability and access to the networks where learning takes place is crucial for the sustainability of the learning economy. 
Table 1: Resources fundamental for economic growth-combining the tangible and reproducible dimensions

\begin{tabular}{|l|l|l|}
\hline & $\begin{array}{l}\text { Easily reproducible } \\
\text { resources }\end{array}$ & Less reproducible resources \\
\hline Tangible resources & 1. Production capital & 2. Natural capital \\
\hline Intangible resources & 3. Intellectual capital & 4. Social capital \\
\hline
\end{tabular}

